\title{
The Use of Radiofrequency Thermal Ablation Method in The Treatment of Hepatic Hydatid Cysts: Ex vivo Sheep Study
}

\author{
Radyofrekans Termal Ablasyon Yönteminin Karaciğer Hidatik Kistlerinin \\ Tedavisinde Kullanımı: Ex vivo Koyun Çalışması
}

\author{
(1) Bekir Sarıc1k ${ }^{1}$, (D) Adil Kartal ${ }^{2}$, (1) Hasan Esen ${ }^{3}$, (1) Mehmet Emin Demircili ${ }^{4}$ \\ ${ }^{1}$ Süleyman Demirel University Training and Research Hospital, Clinic of General Surgery, Isparta, Türkiye \\ ${ }^{2}$ Necmeddin Erbakan University Faculty of Medical, Department of General Surgery, Konya, Türkiye \\ ${ }^{3}$ Necmeddin Erbakan University Faculty of Medical, Department of Medical Pathology, Konya, Türkiye \\ ${ }^{4}$ Necmeddin Erbakan University Faculty of Medical, Department of Medical Microbiology, Konya, Türkiye
}

Cite this article as: Sarıck B, Kartal A, Esen H, Demircili M.E. The Use of Radiofrequency Thermal Ablation Method in The

Treatment of Hepatic Hydatid Cysts: Ex vivo Sheep Study Turkiye Parazitol Derg 2019;43(1):10-5.

\begin{abstract}
Objective: Hydatid disease is a disease caused by parasites belonging to the echinococcus family. This disease is often caused by Echinococcus granulosus and rarely by echinococcus alveolaris. The parasite may cause illness anywhere in the human body, mainly in liver. In this study, we aimed to destroy the hydatid cyst viability by Radiofrequency Thermal Ablation (RFTA) method which has been used in many areas in medicine.

Methods: We used fresh sheep liver with hydatid cysts. Average diameter of cysts was $3.3 \mathrm{~cm}$. The study was performed in 3 groups, each of which involved 20 cysts. After more than half of the cyst fluid was drained, ablation was performed. When the core temperature of the cyst exceeded $95^{\circ} \mathrm{C}$, ablation procedure was continued for 3 minute in $1^{\text {st }}$ group and for 4 minutes in $2^{\text {nd }}$ group. Third group was the control group. And then, cyst fluid and germinative membrane were collected for microbiologic and pathologic assessment.

Results: In $1^{\text {st }}$ group, the cysts could not be destroyed at the desired level. In $2^{\text {nd }}$ group, it was observed that $100 \%$ of the protoscolex died and $100 \%$ of the germinative membranes was degenerated. In control group, $\% 13$ of protoscolex died and \% 10 of germinative membranes wasdegenerated.
\end{abstract}

Conclusion: We destroyed all the protoscolex and germinative membranes by using RFTA in $2^{\text {nd }}$ group.

Keywords: Radiofrequency thermal ablation, hepatic hydatid cysts, liver

Öz

Amaç: Hidatik kist hastalığı, echinococcus ailesine mensup parazitlerin etken olduğu bir hastalıktır. Ülkemizde hastalığın etkeni sıklıkla Echinococcus granulosus, nadiren de echinococcus alveolaris'tir. İnsanda başlıca karaciğer olmak üzere birçok yerde hastalık oluşturabilir. Bu çalışmada, birçok alanda kullanılan Radyofrekans Termal Ablasyon (RFTA) yöntemiyle hidatik kistin canlılığını yok etmeyi amaçladık.

Yöntemler: Çalışmada yeni kesilmiş hidatik kistli taze koyun karaciğerleri kullanıldı. Kistlerin ortalama çapı 3,3 cm idi. Her birinde 20 kist olan 3 grupta çalışma yapıldı. Kist içeriğinin yarısından fazlası boşaltılarak radyofrekans ablasyon iğnesi yerleştirilip işlemler uygulandı. Kist içi sıcaklığ $195^{\circ} \mathrm{C}$ 'nin üzerine çıktıktan sonra 1. gruba 3 dakika, 2. gruba 4 dakika daha ablasyon işlemi uygulandı. Üçüncü grup kontrol grubuydu. Kist sıvısı mikrobiyoloji, germinatif membran da patoloji değerlendirmesine gönderildi. Bulgular: Birinci grupta kist canlılığını yok etmek için amaçlanan etki sağlanamadı. İkinci grupta \%100 protoskoleks ölümü ve $\% 100$ germinatif membran dejenerasyonu tespit edildi. Kontrol grubunda \% 13 ölü protoskoleks oranı ve \%10 germinatif membran hasarı izlendi.

Sonuç: Grup 2'de uyguladığımız RFTA yöntemi ile prtoskoleksler tamamen öldürülmüş ve tam bir germinatif membran dejenerasyonu sağlanmıştır.

Anahtar Kelimeler: Radyofrekans termal ablasyon, karaciğer hidatik kisti, karaciğer 


\section{INTRODUCTION}

Parasitic diseases still threats animal and human health all over the world and cause serious economic losses. Hydatid cyst is one of such diseases.

Although surgical and percutaneous drainage methods are used in the treatment of hydatid cyst, generally surgical treatment is required. Medical treatment alone is not curative (1). It is used supplementary to surgical or percutaneous drainage methods. Percutaneous drainage procedures yield good results in cysts of early stages $(2,3)$. Since conventional surgery is more invasive and involves risks of high morbidity, laparoscopic surgery, which is less invasive, has become more popular.

Ablation of liver tumours using radiofrequency thermal energy still maintains its relevance. Inspired by this, it has been thought that although they are benign especially small cysts that are located in the depths of liver parenchyma can be denatured using radiofrequency.

Therefore, we intended to apply our idea first on cysts in sheep liver in ex-vivo study.

We believe that if the favourable results that we obtained as Ex vivo in liver can be replicated in the clinic, this will bring a new perspective to the treatment of early stage hydatid cysts of liver.

\section{METHODS}

The study was conducted at Necmetin Erbakan University Experimental Medical Research and Application Centre between March 2009 and September 2009 by approval of the ethical committee. Meram medical faculty deanery ethics committe. Approval number: 2009/083. Livers with hydatid cysts of sheep that were obtained from the slaughterhouse and slaughtered fresh under supervision of a veterinary doctor were used in the study. The livers were carried from the place of slaughter to the test location in appropriate maintenance conditions $\left(0^{\circ} \mathrm{C}-+4^{\circ} \mathrm{C}\right)$. Twenty cysts from 9 livers were investigated in group 1 . In groups 2 and 3, on the other hand, 40 cysts from 16 livers were studied.

Cool Type Radiofrequency device (Valleylab, 0-200 watts, 480 $\mathrm{kHz}$ ) and a $17 \mathrm{G}, 15 \mathrm{~cm}$ needle (ACT1520) were used for the thermal ablation procedure. The current device can produce radiofrequency energy manually or impedance-dependently at desired power and for a desired period of time. The impedance range is $25-1000 \mathrm{ohm}$ and temperature range is $10-99^{\circ} \mathrm{C}$. The device can prevent carbonisation around the needle by cooling the electrode tip with cold water. However, this feature of the device was not used in our study as there was no possibility of carbonisation due to the fact that the needle tip got stuck in the cystic fluid.

Assistance was obtained from radiologists during the procedures of measurement and implementation in the selection of cysts from the livers. The cysts were of Type 1 according to Gharbi classification. The study included total of 60 cysts which were 3-3.5 cm in diameter were evaluated by radiologist using ultrasonography (USG).

The livers were divided into 3 groups.

Group 1: The procedure was applied on 20 cysts of 9 livers. The procedure was continued for 3 minutes after the cyst temperature reached $95^{\circ} \mathrm{C}$.

Group 2: In this group, the procedure was applied on 20 cysts from 8 livers. The procedure was continued for 4 more minutes after the temperature within the cystic fluid reached $95^{\circ} \mathrm{C}$.
Group 3 (control group): Twenty cysts from 8 livers were taken for evaluation in this group. The ablation procedure was not implemented.

First, diameters of the cysts in all groups were measured using USG (Figure 1-2). Then, a little more than half of the liquids were discharged using a $21 \mathrm{G}$ needle $20 \mathrm{cc}$ disposable syringe under USG and the syringe was removed. Then, a radiofrequency needle was placed into the cyst under the guidance of USG.

The radiofrequency thermal ablation (RFTA) procedure was initiated for the cysts in the first group with $75 \pm 15 \mathrm{~W}$. After the temperature within the cyst reached $95^{\circ} \mathrm{C}$, the automatic turn-off function of the device, which is sensitive to heat, was deactivated and the ablation procedure was continued for 3 more minutes. Then, the needle was removed. Right after that, the cyst fluid was aspired with a disposable syringe as microbiological specimen and kept at a temperature of $\left(0^{\circ} \mathrm{C}-+4^{\circ} \mathrm{C}\right)$ after being enumerated. The aspirated cysts were subjected to cystotomy and their germinative membranes were removed. They were enumerated and stored in $10 \%$ formaldehyde solution as pathological specimen.

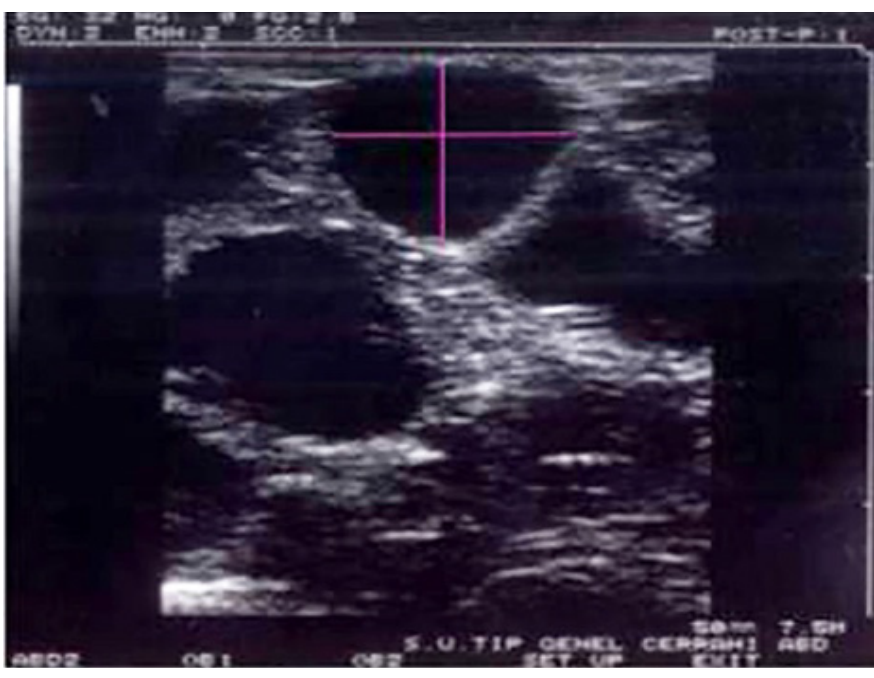

Figure 1. Ultrasonography image of the cyst before radiofrequency thermal ablation procedure (Group 1)

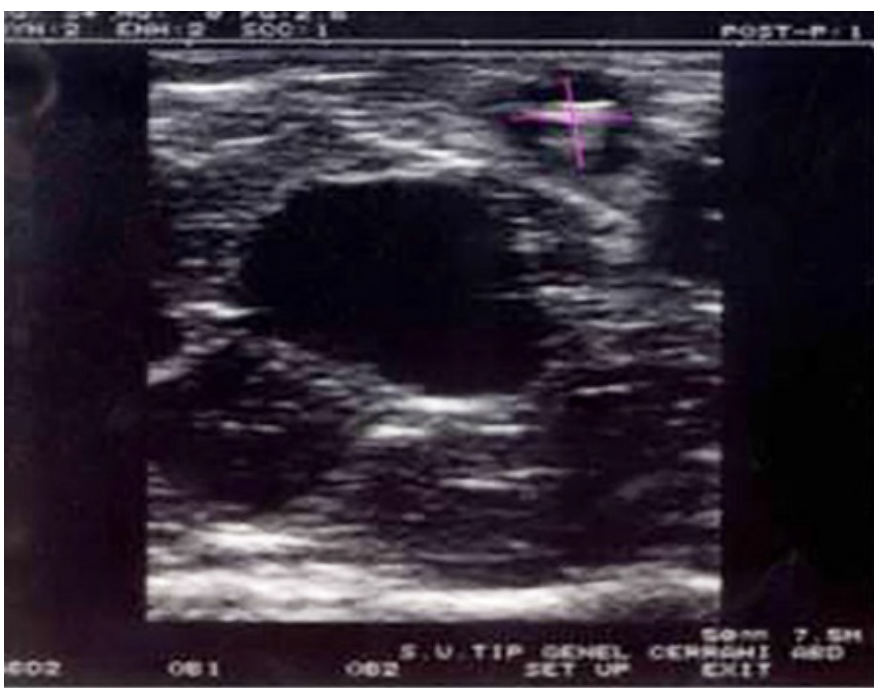

Figure 2. The ultrasonography image of the cyst after the radiofrequency thermal ablation procedure (Group 1) 
The same procedure was applied for the cysts in the second group but the procedure was continued four minutes, more.

A little more than half of the cyst fluid was aspired under USG and radiofrequency electrode was placed into the cysts selected for the third group, which was the control group. The needle was removed without any ablation procedure being applied. The fluid and germinative membrane were enumerated for microbiology and pathology specimen respectively and stored in appropriate conditions.

For microbiological evaluation method one was ensured that protoscoleces settle in vertically held tubes under the influence of gravity $1 \mathrm{cc}$ samples were taken from the supernatant section separately for each sample. They were mixed with $1 \%$ Eosin Y stain and then incubated in drying oven for 5 minutes; 100 protoscoleces were counted for each sample in $10 \mathrm{x}$ and $40 \mathrm{x}$ magnification. Rates of dead protoscoleces that turned pink with Eosin $\mathrm{Y}$ and those that did not color were noted.

Germinative membranes were fixed in $10 \%$ formaldehyde solution for histopathological evaluation. Ten samples were taken from all of the cysts and they were put into a process of tissue follow-up on the autotechnicon (Leica ASP 300) device after being cassette. Subsequent to the embedding of tissues whose followup procedures were completed in paraffin blocks, sectioning was performed in the microtome device. Four micron-thick sections were taken from all blocks onto lysine slides. The sections were stained with Hematoxylin \& Eosin stain. The preparations stained with Hematoxylin \& Eosin were evaluated using Olympus BX51 model light microscope. Percentage values were obtained on the basis of degeneration to germinative membrane in each of the 10 sections in all samples.

Statistical data were entered in the SPSS 13.0 computer software and analysed. Kruskal-Wallis variance analysis was used for intergroup comparisons. Bonferroni corrected Mann - Whitney U test was used for dual group comparisons. $\mathrm{P}<0.05$ was taken to be the significance level.

\section{RESULTS}

A total of 60 cysts were included for evaluation in three groups. Average cyst diameters were 3.3, 3.2 and $3.25 \mathrm{~cm}$ for groups 1, 2 and 3 respectively. No difference was identified among the groups according to an evaluation conducted statistically on the basis of cyst diameters.

\section{Results of the Microbiological Analysis}

91.5\% protoscoleces death was identified in the first group (Figure 3).

$100 \%$ protoscoleces death was identified in the second group (Figure 4).

Although an ablation procedure was not applied in the third group, protoscoleces death was observed at a rate of $13 \%$. Results of microbiological analysis are given in table 1 .

\section{Results of the Histopathological Analysis}

Germinative membrane degeneration was identified at a rate of $90 \%$ in the first group, $100 \%$ in the second group and $10 \%$ in the third group (Figure 5-6, Table 1).

When a between-group evaluation was conducted for results of statistical analysis according to the pathological and microbiological data, it was observed that there was a significant difference among all the groups and within the groups themselves $(\mathrm{p}<0.05$, Table 2).

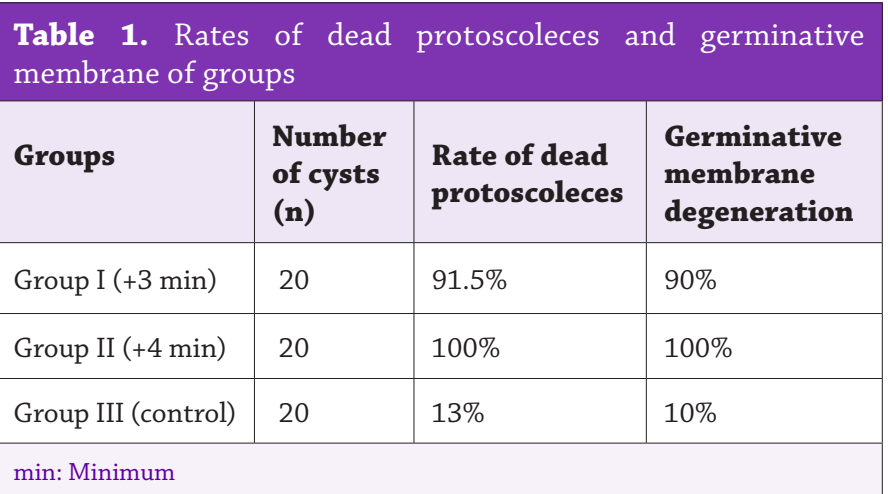

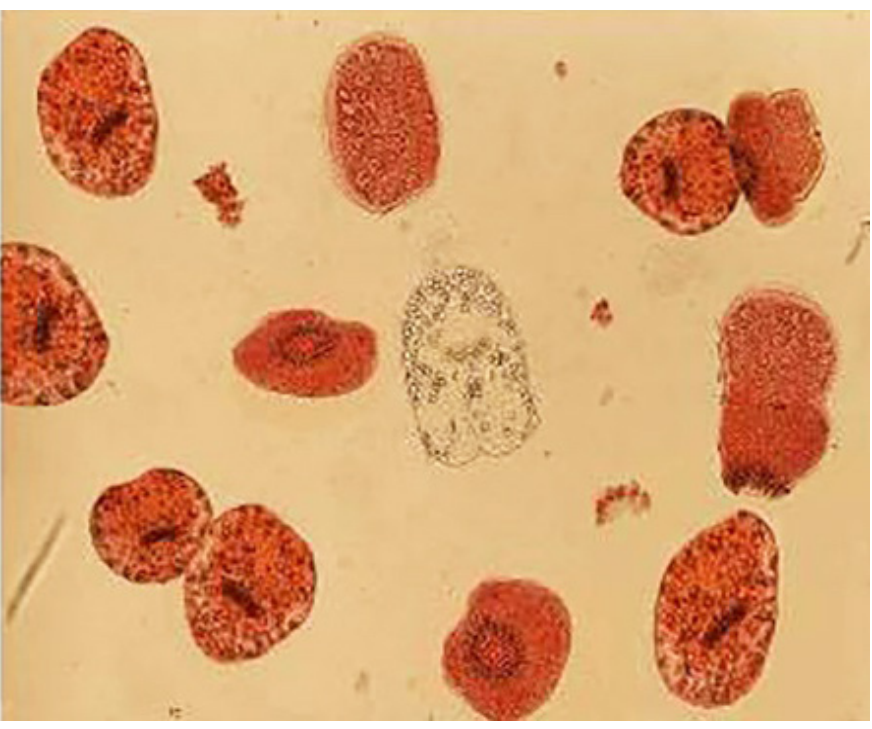

Figure 3. The image of a preparation from group 1 microbiological study under light microscope. There is one live protoscolece in the field that does not stain (Eosin Y stain, x20)

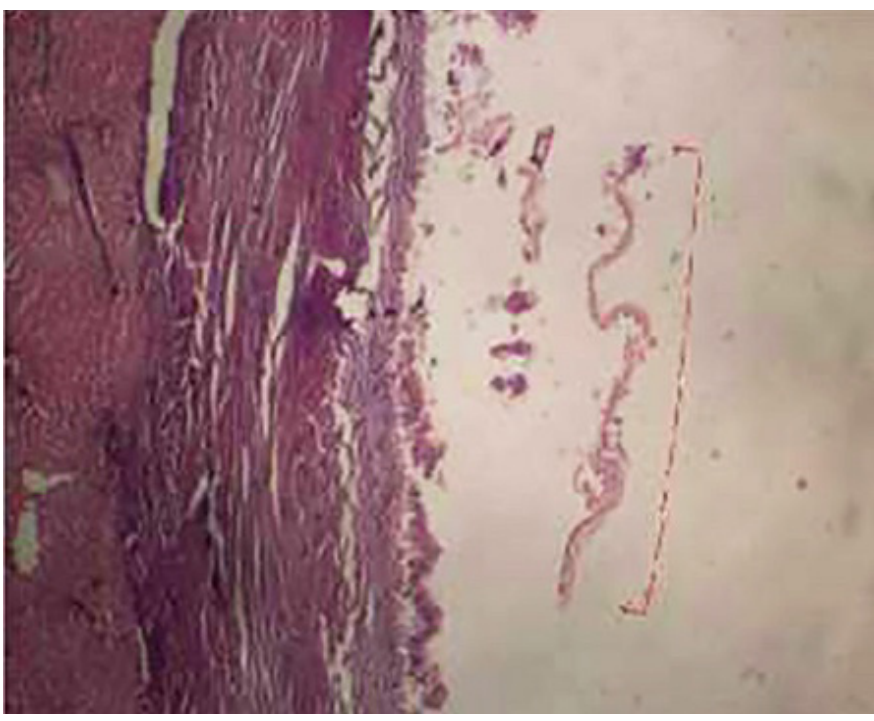

Figure 4. The image of a preparation from group 2 microbiological study that is composed of protoscoleces all of which are dead under light microscope (Eosin Y stain, x 20) 
Table 2. Evaluation results of between-group Mann-Whitney U test

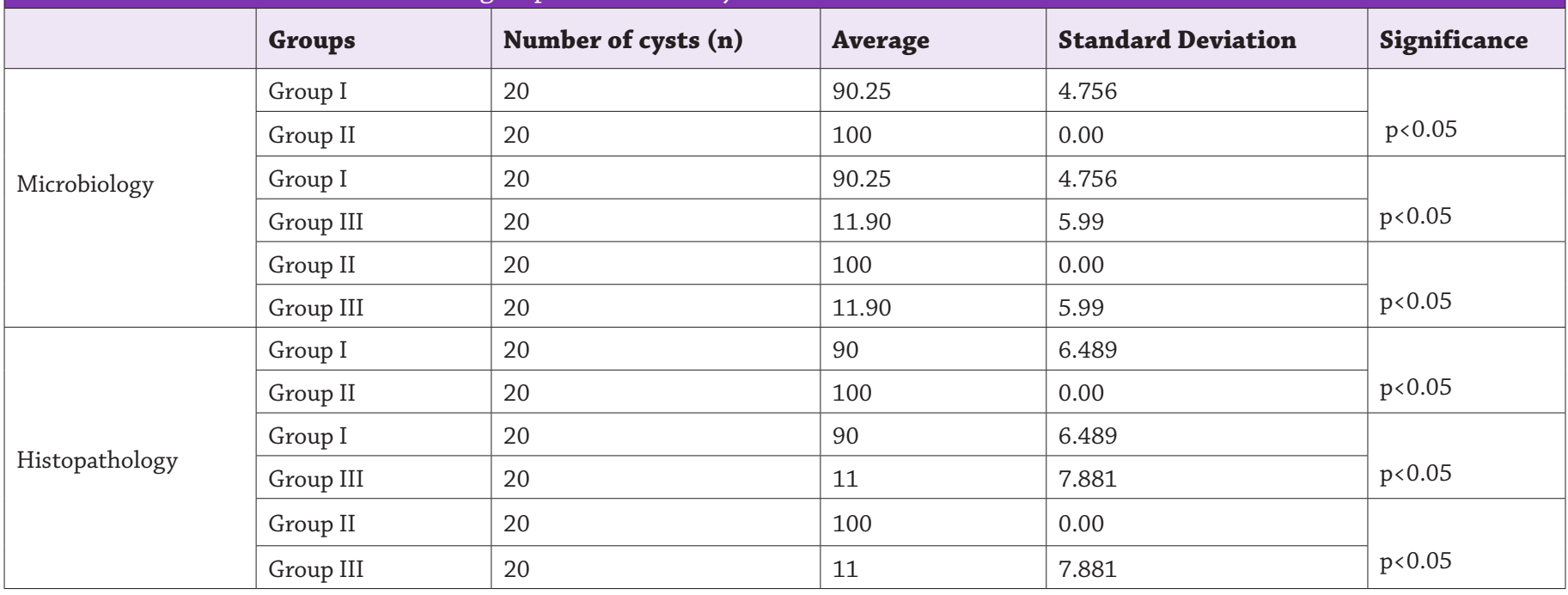

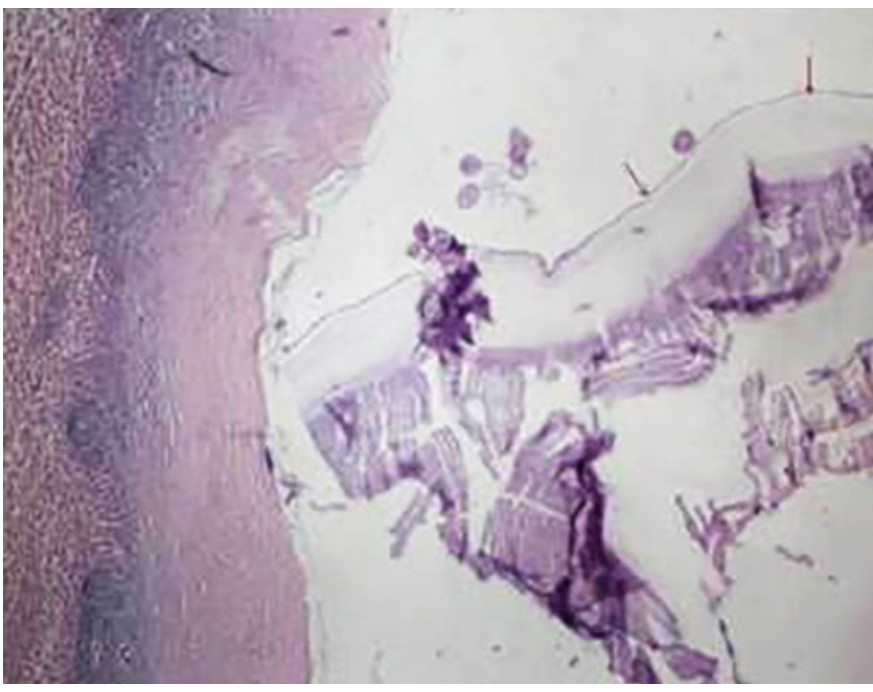

Figure 5. Tissues belonging to liver parenchyma on the left and hydatid cyst on the right are seen in a preparation from a group 2 study (H E, x20)

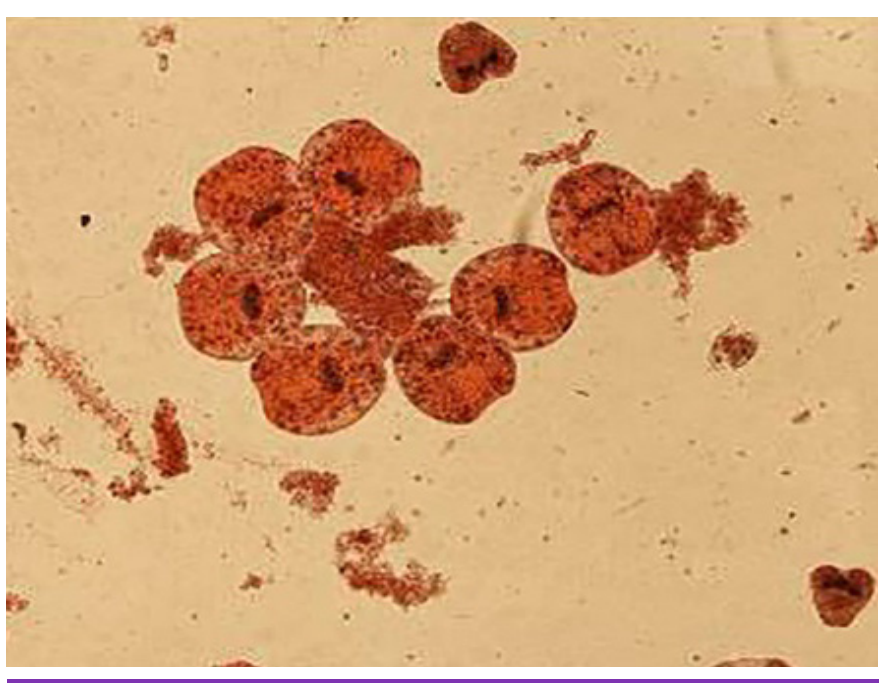

Figure 6. Germinative membrane which is largely healthy in the area indicated with an arrow is seen in an image belonging to group 3 (H E, x20)

\section{DISCUSSION}

The hydatid disease might progresse asymptomatically for long years or appears in a complicated state even when it has been diagnosed. While its treatment is sometimes very simple, it may become so serious as to require liver transplantation $(1,2)$ During the planning of the treatment of liver hydatid cysts, the location of the cyst, its number, type, whether it exhibits symptoms or not, whether it is complicated or not, the facilities of the centre and the experience of the surgeon should be taken into consideration. Medical treatment is not a treatment method on its own, but it is one that is used as a supplement to other methods. Until recently, surgery was considered without alternative in the treatment of hydatid cysts. Although conventional surgical methods maintain their importance in complicated patients, percutaneous applications are used more appropriately especially in the treatment of early stage cysts $(3,4)$. Today, monitoring of advanced stage, asymptomatic and degenerated liver cysts is essential (1).

The cyst in the depths of the right lobe of the liver which is smaller than $4 \mathrm{~cm}$ and not suitable for puncture, aspiration, injection, reaspiration (PAIR) was monitored with antihelminthic treatment. We considered trying RFTA on such cysts as an alternative treatment. Our purpose was both not to use scolicidal and bring an alternative perspective to the treatment of this group which had no alternative other than medical treatment and monitoring. We did not find more than a few works in the relevant literature that could enlighten us on this issue $(5,6)$. The RFTA device firstly was used in the ablation of metastatic tumours of the liver (7). Apart from this, radiofrequency has many other different uses (8-13).

To our understanding small cyst(s) deeply located in the liver parenchyma is not suitable for PAIR or surgery. Medical treatment (albendozal) alone is not alternative to PAIR or surgery. Just it is used before and after both treatments. We think that after puncture the cyst by RFTA needle, destruction of the cyst will be easier and will take shorter time than PAIR application.

So, how to manage small hydatid cyst located in depth of liver parenchyma? Neither surgery nor PAIR have indication in such cases as we said. Medical treatment and follow up looks like 
treatment of choice. But we thought that RFTA application might be other treatment modality for such cases.

As we have already explained that the methodology of PAIR and RFTA is different. PAIR needs to introduce pig tail catheter into cyst. This catheter has distally many holes all of which should be inserted in cyst. This part is about $5 \mathrm{~cm}$ in length. In case of one hole out of cyst the procedure will be insufficient.

Unlike PAIR, the RFTA application kills the protoscoleces in the cysts with thermal energy after puncture and aspiration without using scolicidal agents. During the application, the pressure within the fluid needs to be reduced via puncture due to evaporation of the fluid caused by heating. An application contrary to this may lead to the bursting of the cyst and its spread into the parenchyma. The amount of fluid to be drained away from inside the cyst was determined via pilot studies. The existing RFTA needle possess a canal system that enables water circulation and or steam formation within the syringe in order to prevent carbonisation. Carbonisation does not occur in the hydatid cyst application because the syringe is in fluid.

We have prepared another similar project as in vivo study. We try to get permission from ethical commision to do it on human with hydatid cyst. We changed some points of methodology in the project for example instead of both needles we use one needle and one puncture. We hope that in the future the results will be published.

When we start to do human study small size cysts will be our first cases for denaturation. With time as the experience increases indication will extend for larger cysts as seen in RFTA tumor application. At beginning, RFTA was applied for small lesion then it became indication for bigger $(7 \mathrm{~cm})$ tumor lesion, too.

It is clear that without doing such a Ex vivo study it is to much diffucult to evaluate cyst contents including fluid for protoscoles and germinative membrane after RFTA application. That is why firstly we did this ex-vivo study. In the literature there is just a few cases treated by RFTA and to us is not eligible to make large comment on these cases.

The use of scolicidal agents maintains its importance both in surgical methods and percutaneous applications. There are various scolicidal agents used for this purpose in the literature but most of them have unfavourable side effects $(14,15)$. Especially, injection of scolicidal substance into the cyst should be avoided in cysts that open up to bile tract because this may lead to undesirable conditions such as sclerosing cholangitis. In our study, the scolicidal agent effect was obtained through the thermal ablation property of the radiofrequency waves. However, since our study is an ex-vivo study, it does not provide information about the side effects of radiofrequency. It is necessary to conduct in-vivo studies for his purpose. According to the technical data of the device that used, it provides effective thermal ablation up to a diameter of $3.6 \mathrm{~cm}$ with single needle and a diameter of $5 \mathrm{~cm}$ with cluster needle.

Application of PAIR in cysts with a multivesicular form usually ends in failure. Though some studies refer to scolocidal agents that convert multivesicular cyst into a univesicular one as a result of vesicular wall destruction, this has not taken its place in clinical use yet (16). Apart from this, in methods such as hot water application to produce protoscoleces death and germinative membrane degeneration through thermal impactwill be in sufficient because multivesicular form constitutes a barrier against heat transfer and prevents other vesicules from being affected by the procedure (17). We think that Radiofrequency waves are not influenced by physical barriers and can be effective in multivesicular cysts.

All of the cysts used in our study were univesicular (cysts). We would like to have included multivesicular cysts in our study, too, but almost all of the cysts in the sheep livers were univesicular. The study was conducted on sheep livers by virtue of the fact that the cysts with the highest rates of fertility were in sheep. In our study, we did not take into consideration the damage that would occur in the parenchyma in the immediate periphery of the cyst. We believe that the contraindications that occur in RFTA tumour denaturation should also be considered in cyst hydatic applications in humans.

There are many dead protoscoles in human hydatid cysts depending on type of cyst. The rate of dead protoscoles (13\%) should not be surprised. It can be find such dead protoscoles without dying in aspirated fluid. The same explanation should be valid for germinative membrane degeneration, too.

\section{CONCLUSION}

According to the results of this study, which we conducted on sheep liver with hydatid cysts, when the procedure was continued for 4 more minutes after the temperature within the cyst has reached $95^{\circ} \mathrm{C}$, all protoscoleces have lost their vitality. RFTA still has no place in regular use of treatment of hydatid cyst. We believe that if we can get similar results in in-vivo studies and RFTA application will be alternative modality to surgery in treatment of hydatid cyst.

\section{* Ethics}

Ethics Committee Approval: Meram medical faculty deanery ethics committee. Approval number: 2009/083

Peer-review: Internally peer-reviewed.

\section{* Authorship Contributions}

Surgical and Medical Practices: B.S., Concept: B.S., A.K., Design: B.S., Data Collection or Processing: B.S., Analysis or Interpretation: H.E., M.E.D., Literature Search: B.S., Writing: B.S.

Conflict of Interest: No conflict of interest was declared by the authors.

Financial Disclosure: The authors declared that this study received no financial support.

\section{REFERENCES}

1. Mihmanli M, Idiz UO, Kaya C, Demir U, Bostanci O, Omeroglu S, et al. Current status of diagnosis and treatment of hepatic echinococcosis. World J Hepatol 2016;8:1169-81.

2. Patrono D, Tandoi F, Rizza G, Catalano G, Mirabella S, Celoria P, et al. Liver transplantation with an uncommon full right hemiliver graft after hydatid cysts resection: Case report and review of the literature. Transpl Infect Dis 2017;(3).

3. Chen X, Cen C, Xie H, Zhou L, Wen H, Zheng S. The Comparison of 2 New Promising Weapons for the Treatment of Hydatid Cyst Disease. Surg Laparosc Endosc Percutan Tech 2015;25:358-62.

4. Jabbari Nooghabi A, Mehrabi Bahar M, Asadi M, Jabbari Nooghabi M, Jangjoo A. Evaluation and Comparison of the Early Outcomes of Open and Laparoscopic Surgery of Liver Hydatid Cyst. Surg Laparosc Endosc Percutan Tech 2015;25:403-7. 
5. Thanos L, Mylona S, Brontzakis P, Ptohis N, Karaliotas K. A complicated postsurgical echinococcal cyst treated with radiofrequency ablation. Cardiovasc Intervent Radiol 2008;31:215-8.

6. Brunetti E, Filice C. Radiofrequency thermal ablation of echinococcal liver cysts. Lancet. 2001;358(9291):1464.

7. Wang YH, Liu JF, Li F, Li A, Liu Q, Liu D Bin, et al. Radiofrequency ablation combined with transarterial chemoembolization for unresectable primary liver cancer. Chin Med J (Engl) 2009;122:889-94.

8. Petrou A, Moris D, Paul Tabet P, David Wensley Richards B, Kourounis G. Ablation of the locally advanced pancreatic cancer: An introduction and brief summary of techniques. J BUON 2016;21:650-8.

9. Keltz J, Levie M, Chudnoff S. Pregnancy Outcomes After Direct Uterine Myoma Thermal Ablation: Review of the Literature. J Minim Invasive Gynecol 2017;24:538-45.

10. Diaz-Nieto R, Fenwick S, Malik H, Poston G. Defining the Optimal Use of Ablation for Metastatic Colorectal Cancer to the Liver Without HighLevel Evidence. Curr Treat Options Oncol 2017;18:8.

11. de Baere T, Tselikas L, Gravel G, Deschamps F. Lung ablation: Best practice/ results/response assessment/role alongside other ablative therapies. Clin Radiol 2017;72:657-64.
12. Thompson SM, Schmitz JJ, Schmit GD, Callstrom MR, Kurup AN. ImageGuided Thermal Ablative Therapies in the Treatment of Sarcoma. Curr Treat Options Oncol 2017;18:25.

13. Ringe K, Panzica M, von Falck C. Thermoablation of Bone Tumors. Rofo. 2016 Jun;188(6):539-50.

14. Tripathy S, Sasmal P, Rao Pb, Mishra T, Nayak S. Cetrimide-chlorhexidineinduced multiorgan failure in surgery of pulmonary hydatid cyst. Ann Card Anaesth 2016;19:557.

15. Lashkarizadeh MR, Asgaripour K, Saedi Dezaki E, Fasihi Harandi M. Comparison of Scolicidal Effects of Amphotricin B, Silver Nanoparticles, and Foeniculum vulgare Mill on Hydatid Cysts Protoscoleces. Iran J Parasitol 2015;10:206-12.

16. Örmeci N, Idilman R, Tüzün A, Erdem H, Palabiyıkoğlu M. A New Percutaneous Approach for the Treatment of Hydatid Cyst of the Kidney: Long-term Follow-up. Int Urol Nephrol 2005;37:461-4.

17. Akmatov BA. A thermal method of disinfection of the cavity of echinococcal cyst. Khirurgiia (Sofiia) 1989;(8):123-5. 